\title{
Mann and Gender in Old English Prose: A Pilot Study
}

\author{
Christine Rauer ${ }^{1}$
}

(C) The Author(s) 2016. This article is published with open access at Springerlink.com

\begin{abstract}
It has long been known that OE mann was used in gender-neutral as well as gender-specific contexts. Because of the enormous volume of its attestations in Old English prose, the more precise usage patterns of mann remain, however, largely uncharted, and existing lexicographical tools provide only a basic picture. This article aims to present a preliminary study of the various uses of mann as attested in Old English prose, particularly in its surprisingly consistent use by an individual author, namely that of the ninth-century Old English Martyrology. Patterns emerging from this text are then tested against other prose material. Particular attention is paid to gender-specific usage, examples of which are shown to be exceptional for a word which largely occurs in gender-neutral contexts.
\end{abstract}

Keywords Old English literature · Old English Martyrology · Old English prose · Gender · Translation

\section{Introduction}

The modern English noun man can be said to have three principal meanings: (1) human being, person (irrespective of sex or age); (2) human race, mankind; (3) an adult male human being. ${ }^{1}$ The first two of these can be regarded as gender-neutral, whereas the last has a gender-specific aspect. The second, furthermore, appears to be generic in meaning, whereas the first and last refer to individuals. This combination of gender-specific and gender-neutral, generic and non-generic

\footnotetext{
${ }^{1}$ OED, s.v. man, n. 1; Jespersen (1949, VII, 5.2.2 and 14.3.3.).

Christine Rauer

cr30@st-andrews.ac.uk

1 School of English, University of St Andrews, St Andrews KY16 9AL, UK
} 
meanings is known to have a long history, as it is already present in OE mann, which can similarly mean 'human being (irrespective of sex)', 'man, mankind' and 'male human being'. ${ }^{2}$ Moreover, the overlap of more or less gendered interpretations probably goes back further still to the Proto-Germanic ancestor of man, since gendered and ungendered meanings of this lexeme also appear in other early Germanic cognates, both in West Germanic and North Germanic languages, such as Old High German, Old Saxon, Old Frisian and Old Norse. ${ }^{3}$

Most Germanic languages, however, except for English, at an early stage developed a further gender-neutral term for 'human being' in the form of an adjective-derived noun which survives as, for example, Modern German Mensch ('human being'), and which to some extent took over the gender-neutral function from the various reflexes of man, leaving man in those languages to become increasingly gender-specific in its meaning of 'male human being'. 4 Although a rudimentary type of this adjective-derived coinage existed also in the Old English noun mennisc, 'human being', it never seems to have displaced OE mann to a significant extent; it is relatively poorly attested in Old English and survives in no examples beyond the early thirteenth century. ${ }^{5}$ Man therefore remained in both its various gender-neutral, gender-specific, generic and non-generic meanings in English until the modern period, leading Charles Darwin to entitle his famous nineteenth-century theory of human evolution The Descent of Man, a work which appeared as Die Abstammung des Menschen and De afstamming van de mens in Modern German and Modern Dutch, respectively. And as late as 1961, Carl Jung's work appeared as Man and his Symbols, with Der Mensch und seine Symbole and De mens en zijn symbolen as the German and Dutch titles. Only in more recent times has gender-neutral and generic man seen a drastic reduction in its usage: 'Man was considered until the twentieth century to include women by implication, though referring primarily to males. It is now frequently understood to exclude women, and is therefore avoided by many people. ${ }^{6}$ An increasing reluctance to use this word in a gender-neutral sense arises from the fact that it is more closely associated with male than with female gender, an asymmetry which, as noted above, can be traced back to its Old English ancestor. In general terms, then, the gender-neutral meaning of man has been relatively stable diachronically in both Old English, Middle

\footnotetext{
2 Bosworth and Toller (1882-1898), s.v. mann; Clark Hall (1960) s.v. mann; Roberts et al. (1995), 02.03.01 'people, human being' and 02.03.01.01 'male person, man'; Liebermann (1903-1916, II, 140142).

${ }^{3}$ For Germanic cognates, see Holthausen (1963), s.v. mann; Kroonen 2013, s.v. *mannan-; Kluge and Seebold (2011), s.v. Mann. Inasmuch as meaning can be determined for reconstructed vocabulary, the root seems to have both gendered and ungendered associations at Proto-Indoeuropean level; see Pokorny (1948-1969), s.v. *manu-s and Bammesberger (1999), the latter also on the name mann for the $m$-rune. For further etymological discussion, see also Bammesberger (2000) and Ramat (1963).

${ }^{4}$ Kluge and Seebold (2011), s.v. Mensch.

${ }^{5}$ See the titles cited in n. 1 above, s.v. mennisc; also OED, s.v. mannish, n. See also OED s.v. person II.2. a and human B.1: the latter two terms entered English usage in the Middle English and early modern periods, respectively, but did not altogether displace gender-neutral usage of man. Kjellmer (1973) surveys the wider semantic field of 'people'.

${ }^{6}$ OED, s.v. man, n. 1; Hughes (2000, 322-324). See also Hellinger (1990), esp. 82-105, and the general remarks in Persson and Rydén (1995).
} 
English and Modern English, and has only recently suffered decreased usage; conversely, the gender-specific meaning already present in OE mann has grown diachronically and has very recently become dominant, eventually mimicking the development found in other modern Germanic languages.

\section{Related Semantic Fields and Previous Research}

Many Old English prose texts are derived from Latin sources. Moreover, many Anglo-Saxon prose authors are known to have been bilingual in Old English and Latin and received at least part of their education in Latin. The semantic characteristics of Old English prose could to some extent have been influenced by those of corresponding Latin lexis, and L. homo indeed shares some of the semantic features of mann. In classical Latin, homo primarily means 'human being' or 'person' (in contrast to its gender-specific antonym vir 'adult male human being'); the gender-specific meaning of homo as 'male person' is mainly restricted to preclassical or post-classical Latin. ${ }^{7}$ The later reflexes of Latin homo in the Romance languages also retain the two senses of 'human being' and 'adult male human being' ${ }^{8}$ Biblical usage of Latin homo, moreover, follows that of biblical Greek

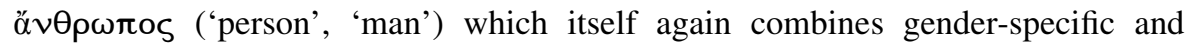
gender-neutral meanings. Homo, therefore, like OE mann, exhibits the same mix of largely dominant gender-neutral denotation with some gender-specific usage and may well have reinforced developments already at work within Old English, as the discussion of biblical material below will show. ${ }^{9}$

The wider Old English semantic field surrounding mann is famously extensive. ${ }^{10}$ One complication for a semantic discussion of mann lies in the fact that many Anglo-Saxon prose authors allow their lexical choices to be influenced by criteria which extend beyond semantic considerations, such as poetic conventions. Despite some fluidity, it is nevertheless possible to show that some vocabulary is clearly more commonly attested in the surviving poetry than in the surviving prose, and Old English lexemes which could be regarded as synonymous with mann and which occur predominantly in Old English poetry include beorn, guma, hoelep, rinc and secg. ${ }^{11}$

\footnotetext{
7 Lewis and Short (1879), s.v. homo, I. B.2; De Vaan (2008), s.v. Homo; Latham and Howlett (1989), s.v. Homo, 1 and 8; Stotz $(1998,361)$.

${ }^{8}$ Meyer-Lübke (1935), s.v. Homo. French feminists have recently queried the wording of the 1789 declaration of the Rights of Man, with respect to the meaning of homme, see The Guardian, 21/05/2015, http://www.theguardian.com/world/2015/may/21/french-feminists-rights-of-man-declaration-petition.

9 For the corresponding semantic field in patristic Greek, see Louw and Nida (1989, 104-107). The general background is summarised in Hastings et al. (2000), s.v. Man/masculinity.

${ }^{10}$ Kastovsky (1992, 400-401); Hughes (2000, 105); Roberts, Kay and Grundy (1995), 02.03.01 'people, human being' and 02.03.01.01 'male person, man'.

11 For a survey of poetic terms for man, see Terasawa (2010) and Godden (1992, 498-499). OE guma, a mainly poetic term, is etymologically related to L homo; see Holthausen (1963), s.v. guma. See OED, s.v. bridegroom, n., for the later fate of this word: 'after gome became obsolete in Middle English, the place of bridegome was taken in 16th cent. by bridegrome, <grome, groom 'lad'.
} 
In prose, perhaps the most important Old English synonyms of mann are wer, wopnedmann, woepned, and woepmann, all of which are more clearly gender-specific than mann in their denotation of 'male human being'. ${ }^{12}$ These gender-specific terms became obsolete during the Middle English period, leaving English with man to cover both the gendered and ungendered senses. ${ }^{13}$ The weak masculine noun manna ('man', 'person') shares the combination of gender-specific and gender-neutral meanings with mann; other synonyms for the gender-neutral generic meaning 'men', 'people' include folc and leode. ${ }^{14}$ Among the Old English words for female person are wif 'woman', 'wife' and wifmann 'woman', 'woman-person', itself a gender-specific term derived from gender-neutral mann. ${ }^{15}$ The later word pair 'man and wife' appears in Old English most often as the alliterating wer/wif, occasionally also as ceorl/wif (Curzan 2003, 158-172).

Modern research has seen some interest in Old English gender-specific terms for a person. ${ }^{16}$ In the area of historical linguistics, detailed morphological or semantic studies have been produced, for example, on gender-specific suffixes or gendered word pairs, often with particular attention paid to female and feminine elements. ${ }^{17} \mathrm{It}$ is worth noting that published studies have typically shown an interest in gendered language when dealing with less common vocabulary and possible anomalies in gender references: among the less frequently attested terms from the semantic range of man which have been researched are OE husbonda, Old English vocabulary for 'lord' and 'boy', and Old English poetic terms for 'warrior'. ${ }^{18}$ The early English lexis relating to sexuality and particularly homosexuality has also received detailed discussion in recent times. ${ }^{19}$

No systematic large-scale studies have been undertaken on particularly the most frequently attested lexis with reference to gender in Old English texts. The reason why the semantics of very common gendered vocabulary remains under-researched lies of course precisely in its ubiquity and the resulting difficulties in surveying such

\footnotetext{
$\overline{12}$ OE wer and L vir are cognate on an Indo-European level; De Vaan (2008), s.v. vir. In modern English, the element survives in werewolf, see OED, s.v. werewolf, $\mathrm{n}$.

$13 \mathrm{Wer}$, still attested in the late twelfth-century Ormulum (Patt hallghe were Symeon 1. 7615), seems to have been the first of the terms to become obsolete during the Middle English period. For the corresponding Middle English semantic field, see Stenroos (2002), Kleparski (2003), esp. 48, and Curzan (2003, 171).

14 di Paolo Healey et al. (2008), s.v. folc; Kjellmer (1973), esp. 51-53 for comparison with mann. For manna, see Terasawa (2010).

15 Roberts, Kay and Grundy (1995), 02.03.01.02 'female person, woman'. For some discussion of wif in connection with mann, see Curzan (2003, 62-63 and 158-172); Hogg and Fulk (1992-2011), 66.

${ }^{16}$ For male gender terms in English cognitive linguistics, with particular reference to conceptual blending, see Grygiel (2004), Grygiel (2006), and Grygiel (2008).

17 von Lindheim (1958), Kornexl (2006, 2009), Kastovsky (1999), Fell (2002). Less nuanced is Riedinger (1994).

18 Kornexl (2006), Stibbe (1935), with a brief section on mann, 32-33; Grygiel (2004), Kleparski (1996), Bäck (1934), esp. 168-171; see also Fell (2002), 208-209 for interesting remarks on ealdormann and pegn. I have not seen Chase (1977).

19 Coleman (1999); for the Old English lexis of homosexuality, see, for example, Frantzen (1996), Fulk (2004), Clark (2009), esp. 54-67; useful concise contextualisations can be found in Frantzen (2012, 114$117,175-178$ and 244-247).
} 
unwieldy semantic fields: some 10,000 attestations of OE mann and its oblique forms alone have been charted; ${ }^{20}$ spelling variations further complicate the picture. $^{21}$ The task of surveying such an extensive lexical field seems difficult enough, even if one discounts examples of the Old English indefinite pronoun man ('one'), whose etymological development and usage are linked to that of mann. ${ }^{22}$ Similarly, no systematic semantic studies exist for OE wer and OE wif and wifmann. Existing lexicographic entries for mann were compiled without recourse to electronic tools, whereas the ongoing Dictionary of Old English, which bases its work on the systematic use of searchable databases, has not reached the relevant part of the alphabet. ${ }^{23}$ Beside dictionary entries, some comparative semantic surveys exist in the form of more specialised reference works such as the Thesaurus of Old English and Julie Coleman's study of the lexical field of love, sex and marriage, both of which highlight the sheer volume, variety and diachronic complexity of this semantic range, without, however, being able to offer much analytic discussion or literary contextualisation. ${ }^{24}$ In the most extensive and helpful discursive analysis to date, Anne Curzan has included the diachronic usage of OE mann in her discussion of gender development in historical linguistics (Curzan 2003, esp. 62-65 and 162-165). ${ }^{25}$ The range of textual examples presented by Curzan suggests great semantic variation in the meaning of mann, including application to named women (at the gender-neutral end of the semantic spectrum) and to males in sexualised contexts (at the gender-specific end). Intriguingly, Curzan hints at a gradual and somewhat latent development from gender-neutral to gender-specific denotation even within the Old English period (Curzan 2003, 163164). The question now arises as to what governs such usage at these extreme ends of the semantic spectrum. The aim here is to examine mann in the gendered context of a particular narrative text. A further aim is to test the tensions between genderspecific and gender-neutral denotation as 'male human being' and 'person, human being' respectively: to what extent did these overlapping denotations cause problems? Christine Fell warned against possible misunderstandings and mistranslations of mann, noting 'the extent to which our response to some of the simplest words can blur our understanding of the original. We are, in modern English, accustomed to read the word man as masculine, even though we know that in certain

\footnotetext{
${ }^{20}$ Citing the Helsinki Corpus of English Texts, Curzan (2003, 135n) refers to some 10,000 attested Old English and early Middle English examples of mann; the DOEC, di Paolo Healey et al. (2005), lists some 11,000 attestations of OE mann and its oblique forms.

21 Spelling variation of mon- for man- reflects nasalisation and later rounding; see Campbell (1959, §130), Lass (1994, 41-42), Hogg and Fulk (1992-2011), I, 75-76.

22 Mitchell (1985, §§ 363-377); Curzan (2003, 64), van Bergen (2003); see also Fröhlich (1951), and the remarks by Mitchell (1982).

23 For erroneous etymological links between OE mann and OE mān 'crime' found in nineteenth-century lexicography, see Bankert (forthcoming).

24 Roberts et al. (1995), 02.03.01 'people, human being' and 02.03.01.01 'male person, man'; Coleman (1999). For further bibliographical information, see Cameron et al. (1983), s.v. mann. Particularly for modern gendered vocabulary and theoretical background, see also the contributions in Persson and Rydén (1996).

25 Also useful are Baron (1986), esp. 138-139, and the critical comments in Fell (2002).
} 
contexts (e.g., 'mankind') it is used of human beings of both sexes. But our primary assumption in most contexts will be that it refers to the male. Old English mann, however, can equally be used of women' (Fell 1984, 17). ${ }^{26}$ The questions therefore are: when is it used in such a way, and under what circumstances? What are the resulting implications for translators of Old English?

\section{Usage of OE Mann in the Old English Martyrology}

The Old English Martyrology, a ninth-century encyclopedia of saints' biographies, is one of the longest prose texts written in Old English, probably by a single author. Greatly influenced by its Latin sources, which it follows very closely, the text is largely free of rhythmical or alliterative patterns. ${ }^{27}$ With its focus on both devotional and secular detail, the narrative presents a wide range of examples from the semantic field of 'man': of 238 text sections, 110 contain attestations of mann, which makes it one of most frequently used nouns in this text. The aim of this section is to present a case study outlining the various usages of mann and a number of synonyms and other gender-related vocabulary in this text. The following miracle narrative concerning St Martial, the first bishop of Limoges, describes two people (or men?) having sex in a church and may serve as an opening example here:

Pæt wæs pæra wundra sum pæt twegen men on sumum ende pære cyrcan hig gepeoddon hig tosomne myd unryhthæmede. Pa wæron hig sona aworpene of pære cyrcan, swa hig sylfe nyston hu pæt gedon wæs; næs pær duru ontyned, ne weall toslyten, ne eahpyrl geopenod. And pa ne myhte hyra naðer fram oðrum beon aðyded, ær pam on morgen heora unryhtwysnys wæs geopenod eallum folce, and myd pæs folces bene hig wæron gefreod fram pære sceandlican dæde. ${ }^{28}$

One of [St Martial's] miracles was that two people joined in illicit sex together somewhere inside the church. Then they were straightaway thrown out of the church, in such a way that they did not know how that had been done; the door had not been opened, nor the wall been torn down, nor the window been opened. And then neither could be separated from the other, before in the morning their wrongdoing had been revealed to all people, and through the people's prayers they were delivered from the shameful deed.

The text's first editor, Georg Herzfeld, translated the reference to the copulating couple as gender-specific, twegen men, 'two men', influenced perhaps by modern English or German usage, and was followed by subsequent scholarship which also located a homosexual couple in this text. ${ }^{29}$ The Latin source of this text is the

\footnotetext{
${ }^{26}$ For similar points, see also Fell (2002, 201-211).

27 On the text's style and mode of composition, see Rauer (2013b, 11-18).

28 Old English Martyrology, ed. Rauer (2013b, 116); references to this text are by section number.

29 Herzfeld (1900, 110-111 and 231); that Herzfeld has the gender-specific meaning of modern English 'men' ('males' not 'people') in mind is made clear in his comments on p. 231. See also Whatley (2001, 329) and Rauer (2013b, 270).
} 
Miracula S. Martialis (BHL 5561), 245.7-19, where the lovers are, by contrast, clearly identified as a man and a woman (mulier) and their sex as shameful; no textual variation of this heterosexual pairing can be found in individual manuscript versions of the Latin narrative. ${ }^{30}$ The author of the Old English text normally adheres very closely to his Latin source material, a principle which would here suggest a gender-neutral translation of men as 'people' as the only option overlapping with the details of the Latin text. Theoretically, however, twegen men could refer to two men, or two women, or a heterosexual couple. Did the author switch to a homosexual couple with a gender-specific reference to men, or intentionally hide the true gender of the couple with a blurring gender-neutral reference to men? In order to decide more firmly what the Old English author had in mind with twegen men, it is necessary to examine his more general usage of mann and related vocabulary in this particular text.

As a piece of early medieval hagiography, the Old English Martyrology is fairly typical in its distinction of female and male gendered treatment of the saints at the centre of the text; as in late antique hagiography, female martyrdoms in particular are frequently gendered in the sense of being linked to a female saint's pagan betrothal, pre-marital sex, or sexualised body parts (breasts, for example) (Rauer 2013a; Stodnick 2013). In other words, female saints often die in a peculiarly 'female' way, and for 'female' reasons, whereas the gender shared by male saints and male persecutors largely rules out sexualised treatment. Equally typical is the text's distinction between morally virtuous characters central to the narrative (that is, the saints themselves), their morally reprehensible opponents (persecutors), and morally neutral or benevolent bystanders and crowds. ${ }^{31}$ Hagiography typically prescribes sexual abstinence for the saints, with open criticism of oversexualised behaviour in other characters, and only marital sex as acceptable in side characters. In introducing his male saints, the author most often uses designations of ecclesiastical office (such as 'pope', 'bishop', 'archdeacon', etc.); the term martyr is also frequently applied to male saints (Rauer 2013a, 18-20). The female saints, by contrast, with their lesser potential in terms of ecclesiastical office, are referred to as 'virgin', 'queen', 'abbess', 'widow'; a number of female saints with a sexual past are also designated as prostitute saints, with a number of derogatory terms (Rauer 2013a, 19-20). The word martyr is not applied to female saints in this text, although martyrdom is.

Some saints are gendered by being referred to as wer 'man' or wif 'woman', which constitute perhaps the most explicitly gender-specific terms in the semantic

\footnotetext{
30 Vita S. Martialis (BHL 5551) and Miracula S. Martialis (BHL 5561), ed. Arbellot (1892, 213-260, at 238-248). BHL 5561 is contained in Rome, Biblioteca Nazionale, Farfa 29 (341), 138v-143; Brussels, Koninklijke Bibliotheek van België, 8550-8551 (3203), 17v-24r; Paris, Bibliothèque Nationale de France, lat. 3851 A, 30v-32v; Paris, Bibliothèque Nationale de France, lat. 5365, 34r-41v; Paris, Bibliothèque Nationale de France, lat. 5322, 140r-141v. Similar narratives involving penis captivus with miraculous release occur elsewhere in medieval and early modern literature; see Rolleston (1991, 232237) and Loomis (1991, 237-238).

${ }^{31}$ For the role of the witnessing crowd in Christian miracles, see Theissen (1983, $48-49$ and 69-72), Bultmann (1963, 225-256), van der Loos (1965, 129-130).
} 
field of 'man' in this text. ${ }^{32}$ Particularly male saints not otherwise holding ecclesiastical office are described as wer $(29,32,38,40,49,67,100,120,121,152$, $160,161,166,173,176,207,207,211,232)$; the collocations Godes wer $(176,211)$, halig wer $(32,67,100,121,173,196)$ or apel wer $(38,40,67,120,232)$ also occur. Pairs or groups of male saints venerated as a unit, on the same feastday, like Abdon and Sennes, are relatively frequently referred to as weras $(41,98,99,103,106,113$, $114,139,182,191,195,222,224)$. For characters other than the saints themselves (thus side characters), wer tends to be used particularly in cases emphasising sexuality, courtship, or respectable maturity: 1 (no wer touched the virgin Mary), 3 (the saint's father), 90 (suitor), 110 (the female saint's two husbands), 112 (no wer allowed near female saint), 124 (heathen suitor), 130 (suitor), 227 (noble suitor), 70 and 145 (friendly helpers), 178 (a famous man, morally neutral). Wer is also employed in the description of angelic figures and apparitions $(51,73,187)$.

Similarly, a number of female saints are characterised with the gender-specific wif $(29,38,43,87,99)$, or halig wif $(2,39,118)$, gesipwif (2). The connotation seems to be one of mature and official marriage or coupledom in these cases, which is also true for the reference to Eve as a wif (53). A number of references to courtship, sexual approaches and sexual unions also use wif $(22,30,94,122,168$, 207, 211). Even more often than the saints themselves, side characters are referred to as wif $(76,102,117,122,168,173,183,190,194,198,203,217,220,225,228$, $231,233)$. In many cases such a wif is in a position to help a more vulnerable male saint, with her implied maturity perhaps eliminating the possibility of sexual interest on her part in a chaste male saint. The text also describes several cases of a wif acting autonomously outside her home, in contrast to the figure of the less autonomous famne ('virgin', 'young woman', 'pre-sexual woman'), ${ }^{33}$ a term very often applied to the female saints themselves, often as halig fomne (15, 24, 30, 33, 61, 90, 122, 189, 193, 227), Godes fomne or Cristes fomne (8, 112, 190, 211, 234, 235); the term 'nun' is very rare in this text (190). The Virgin Mary is also a foemne $(1,111)$. Fomne is less often applied to side characters $(74,211)$, perhaps again so as not to provide a sexual target distracting from the vulnerable female saint designated in the same way. Famne does not occur paired with wer except in 13, where religious communities for men and for women are intended; religious communities exclusively for men use wer $(3,13)$. Wer is, however, often paired with wif $(12,57,78,111,128,207,210)$. Several instances of female saints acting as transvestite males are described as wer or with the adjective werlic $(3,39,193)$, with reference to their gendered male behaviour and appearance.

The usage of mann in this text differs in several respects from that of wer. The word mann seems to be predominantly gender-neutral and restricted to side characters. Strikingly, only a single saint is referred to as a mann, and that not by a narrator, but, perhaps disparagingly, by characters in the narrative: a monastic community complains to the abbot about the austere example set by their brother Simeon Stylites, Tohwon gelceddest pu pysne mon to us? Forðon ne magon we arcefnan his heard peawas 'Why do you bring this person to us? We cannot bear his

\footnotetext{
32 Wapnedman and ceorl do not occur.

33 di Paolo Healey et al. (2008), s.v. famne.
} 
tough manners' (136). Beside this example, mann is restricted to side characters, which include instances of an executioner $(64,98,109,113)$, numerous instances of a dead man awakened or a sick man healed (13, 18, 56a, 77, 97, 111a, 152, 186, 209), a blind man healed $(15,92,134,178,221)$, or other (pious, noble, evil, etc.) side characters $(3,4,5,36,38,80,82,91,136,186,209,211,214,232)$. In many of these instances of singular usage applied to a single unnamed (and thus ungendered) character, it proves difficult to tell whether the author intended gender-specific or gender-neutral meaning (and as observed earlier, plural references to small groups can cause similar problems). For example, when it is said of Augustine of Canterbury that he sealde blindum menn gesihðe, 'he gave sight to a blind person/man' (92), the author may not have cared that much about the person's gender. Consultation of Latin sources can sometimes shed more light on whether gender-neutral or gender-specific mann was on the Old English translator's mind, but as demonstrated above in the case of the fornicating churchgoers, an AngloSaxon author may well tolerate a gap between the gender-specific detail of a Latin source and an Old English translation which fudges this detail into genderneutrality. For this author, the important point in the cited episode seems to be that sex in church is bad, irrespective of the participants' gender, which requires no specification. It seems that particularly these ambiguous cases referring to unnamed individuals are often the trickiest cases for a modern translator.

Other contextual knowledge (arising from names and socio-historical background) can also help in determining the difference between gender-neutral and gender-specific authorial intention. An example is the narrative concerning the person who shoots a bull in St Michael's cave, and is in return hit by his own arrow (82): se mon waes ofscoten mid his agenre strcele, mid py pe he wolde done fearr sceotan, 'the man was shot with his own arrow, when he tried to shoot the bull'. The masculine grammatical gender of anaphoric pronouns here probably occurs by default, via the so-called inclusive or generic masculine, and cannot on its own be seen as an indicator of a male referent. ${ }^{34}$ But a translation of mann as 'man, male' here is also confirmed by assumptions concerning hunting activity and arrow ownership in early medieval Italy, which are likely gender-specifically male, reinforcing a translation of 'male'. Into a similar category of mann with circumstantial gender-specificity belong the references to executioners (see above), a scholar (232), and side characters given a male name (4, 209). Perhaps the most clearly gender-specific examples of mann in the Old English Martyrology occur in the three cases of female saints being approached by a mann for sex or marriage (3, $38,211)$ : in these cases, it is difficult to explain why the potentially ambiguous and gender-neutral mann was chosen over the consistently gender-specific wer. An important corollary here is that a clear-cut distinction between gender-specific and gender-neutral use of mann may not be possible for a modern translation of this text, nor may have existed in the author's mind. Instead, it is perhaps helpful to think of gradations of gender-specificity.

\footnotetext{
34 Curzan (2003, 58-82), Hughes (2000, 342-344), Hellinger (1990, 36-38), Kornexl (2009, 88-89), Mitchell (1985, $\S 69$ and 71). But it is known that wifman can occur with feminine anaphoric pronouns, despite its masculine grammatical gender (although in those cases there can be no doubt about a female referent). See, for example, MCharm 6, Dobbie (1942, 123-124).
} 
Singular or plural usage of mann in the Old English Martyrology can also generically denote mankind $(12,106)$, particularly with reference to the human body, parts of the body, or bodily measurements $(1,58,73,79)$ and man's salvation $(49,57,78,88,114,149,195)$. Mann is also frequently used in plural forms to denote crowds, for example, groups witnessing miraculous events. ${ }^{35}$ Plural mann also refers to needy groups requiring saintly help: the dead (5, 56a, 70, 74, 138, 176, $223)$, the poor $(130,151)$, the blind $(3,89,151,203)$, and the sick $(1,3,70,145$, $186,198,217,236)$. The suggestion again seems to be that the gender of the people involved is of no concern to the author; narrative logic indeed demands an ideally wide gender and age range among the referents: Christian healing does not discriminate. Gender-neutral translation therefore often seems the most appropriate in these cases. Sanctus Marcus hoelde untrume men ond hreofe, ond deade men of deaðe awehte, 'St Mark healed sick people and lepers, and he resuscitated dead people from death', 70 .

Collocations involving plural forms of mann also include references to Christians (Cristene men, 26, 31, 32, 35, 38, 56, 76, 79, 97, 102, 103, 105, 149, 203, 228, 234, 235) and heathens (hopene men, 5, 19, 116b, 122). Mann also occurs in collocations with indefinite adjectives like oenig, noenig, celc, hwilc, leading to translations of 'anybody', 'nobody', 'everybody', 'whosoever': Forpam nat noenig man, 'therefore nobody knows', 5, 22, 52, 61, 73, 83, 97, 111, 122, 133, 140, 168, 173, 198). Mann is furthermore used in references to national or regional identity, Grecisces cynnes mon, 'person of Greek nationality' $(10,17)$, and, with possessive pronouns, in descriptions of military followers or servants, his agene men, 'his own men', hyre men, 'her men' $(26,59,203)$.

Christ is invariably characterised as mann in the Old English Martyrology (12, $79,111,130,133,210)$, never as wer, although the adjective werlic, 'manly', 'male', is used in the account of Christ's foreskin being removed in the circumcision account (9), representing the most gendered detail concerning Christ's physicality. Usage of mann for Christ, which of course emphasises his human nature, even occurs when Christ manifests himself in dream-like apparitions which initially disguise his identity $(130,223)$, and it is significant that this usage is in contrast with the text's usage of wer involved in other angelic apparitions (see above). Adam is referred to as se ceresta man, 'the first human being' (53), most likely neutral in gender and with emphasis on his human nature. Other gender-neutral references in the text associate mann with 'first-of' or 'only ever' record-setting events $(53,135$, 168, 190).

To return to the couple fornicating in church: translation of gender-neutral 'people' seems the correct option, for its compatibility with the Latin source and for the author's normal practice of leaving non-saintly side characters fairly unspecific in gender terms. The narrative focus is on the saint protecting his shrine miraculously, with a socalled revenge miracle. The vague reference to the couple may appear unspecific for our modern understanding, given the highly sexualised action the two are meant to be engaged in, but may serve as a reminder of the textual aim. Had the martyrologist wanted to characterise the offending couple as two men engaging in same-sex

\footnotetext{
35 Usage of folc in this text, not surveyed here, shows similarities.
} 
intercourse, weras would, given his general lexical preferences, have been the more obvious option as a gender-specific synonym, or usage of a derogatory gender-specific term, as is used for oversexualised females in this text. ${ }^{36}$

To judge from this pilot study, it seems that in the vast majority of examples in this text, wer (always gender-specific) and mann (very rarely gender-specific) are, on the whole, not semantically interchangeable. The usage of mann in the Old English Martyrology seems surprisingly consistent. For the sake of a more complete picture, it is important to note also what does not occur: no individual named saint, neither male nor female, is called a mann by the narrator, as if greater genderspecificity was required for the description of the main characters. The author does not seem intent on demonstrating the humanity of his saints; his interest lies more in specifying the ecclesiastical status of his protagonists. Among examples of mann, gender-neutral usage is the default in this text, but is not pushed to its limits: there is no attestation of mann applied to a specific named woman, which is a possibility in other texts, as the next section will show.

\section{Mann in Other Old English Prose: Correspondences and Differences}

Given the semantic instability of man noted at the beginning of this discussion, it is interesting to see that the usage patterns emerging from the Old English Martyrology overlap with a good number of attested meanings in the Middle English Dictionary and with those meanings listed in the Oxford English Dictionary for which premodern attestations exist. ${ }^{37}$ To what extent these patterns also apply for other Old English prose can be shown with further textual examples intended to place the evidence cited so far in a wider literary context. ${ }^{38}$

Numerous references to Christ as mann can easily be located in the corpus of Old English prose, and are clearly linked to the concept of his humanity. His identity as the Son of Man appears as mannes sunu in Old English (ca. 153 occurrences), in a clear example of gender-neutral mann, here understood to refer to the Virgin Mary and her human ancestry; the hypothetical weres sunu by contrast seems to be unattested in connection with Christ, which is unsurprising since Christ cannot possibly be the son of a gender-specific wer, a human male. ${ }^{39}$ Emphasis of Christ's

\footnotetext{
36 No vocabulary related to homosexual sexuality is used in this text; for details see di Paolo Healey et al. (2008), s.v. baedling; Bosworth and Toller (1882-1898), s.v. sodomisc (adj. used as n.); for semantic background, see the titles cited in footnote 19 above. The term gesinhiwa (pl. 'couple') does occur twice in the text, but that seems to be applied to a legitimate couple (married or in bed) who are characterised as morally virtuous.

37 MED, s.v. man, 1a, 2a, 2b, 3a, 5, 7, 8a; OED, s.v. man, 1a, 1b, 1c, 2a, 4a, 5a, 14.

38 Textual examples discussed were located with the help of the DOEC (simple searches and proximity searches) and are referred to with the titles used by the DOEC. For the sake of clarity, my translations over the following pages are intentionally emphatic in distinguishing the modern English gender-specific 'male' and the gender-neutral 'human being' and 'individual', irrespective of stylistic oddities.

39 Cross and Livingstone (1997), s.v. Son of Man; the concept appears as 'Menschensohn' and 'mensenzoon' in Modern German and Modern Dutch respectively, for example. See also Bennett (2012, 143-145) for references to Christ in Ælfric; see Scheller (2010, 154-155) for references to Christ as gastsunu, and Scheller (2010, 160-161 and 326) and di Paolo Healey et al. (2008), s.v. guma, subsection
} 
identity as mann in particular seems to be 'a favourite Ælfrician comment' (Godden $2000,561)$, as the following two passages show: ${ }^{40}$

He is on twam gecyndum an crist. soð man. and soð god. and se mannes sunu is godes sunu. and se godes sunu is mannes sunu. anes mannes swa we ær cwædon. Marian pæs mædenes. ${ }^{41}$

He is one Christ with two natures, true human being and true God, and the son of the human being is God's son, and the God's son is the son of the human being, one human being's as we earlier said, namely that of the virgin Mary.

Crist is ana mannes bearn, anes mannes, and na twegra, mædenes and na weres. $^{42}$

Christ is the one and only child of a human being, of one human being, and not of two, of the virgin and not of the male.

Linked to Christ's humanity is that of the Virgin Mary, here exemplified as mann in a way not familiar from the Old English Martyrology:

Crist sylf is mannes bearn, se pe is anes mannes sunu, pære eadigan Marian on pære menniscnysse. ${ }^{43}$

Christ himself is the child of a human being, he who is the son of one human being, of the blessed Mary in the human image.

Other passages focus on the Virgin Mary alone: Nis nan wifhades mann hire gelica, "no person in womanhood is equal to her" ${ }^{44}$; heo is gebletsod ofer eallum wifhades mannum, 'she is blessed above all individuals of womanhood' ${ }^{45}$ In their humanity, Christ and Mary are also linked to Adam and Eve, who are both frequently described as mann, for example, by Ælfric:

On ðam sixtan dæge he gesceop eal deorcynn, \& ealle nytenu pe on feower fotum gað, \& pa twegen men Adam \& Euan. ${ }^{46}$

On the sixth day he created all wild aminals and all domestic animals walking on four legs, and the two human beings, Adam and Eve

If mann is contrasted with animal life here, further subcategories are wer and wif, showing very clearly the difference between gender-neutral and gender-specific

Footnote 39 continued

c.i. for Christ as guma. For biblical imagery emphasising Christ's masculinity, see O'Brien (2014, 374375).

${ }^{40}$ Further examples given by Godden are ÆCHom I, 40, lines 68-69, Clemoes $(1997,526)$ and ÆCHom II, 7, lines 138-140. See also the glossary in Godden (2000, 738), s.vv. mann and manna.

41 ÆCHom II, 28, Godden (1979, 224).

42 ÆCHom II, 28, Godden (1979, 224).

43 HomU 44 (Nap 55), Napier (1883, 288), a passage itself based on ÆCHom II, 7, Godden (1979, 65).

44 ÆCHom II, 1, Godden (1979, 5).

45 ÆCHom II, 1, Godden (1979, 11).

46 ÆTemp, Blake (2009, 76). 
usage of mann and wer, with Eve qualifying as a mann but of course not a wer, as Adam does: God gesceop da cet fruman twegen men, wer and wif, 'then at the beginning, God created two human beings, man and woman'. ${ }^{7}$

Perhaps the most striking use of gender-neutral mann is the one applied quite explicitly to other named females, for example, when the Anglo-Saxon Chronicle (EF) refers to Eorcengota as a hali femne \& wundorlic man, 'a holy virgin and remarkable person'. ${ }^{48}$ Several other female saints are described in similar terms in the Old English corpus, for example, Helen and Agatha by Ælfric: His modor waes cristen. Elena gehaten. swiðe gelyfed mann. and ðearle eawfast; ${ }^{49}$ 'his [i.e. Constantine's] mother was a Christian; [she was] called Helen, a very devout individual and firmly pious;' and Hwat ða Agathes inwerdlice clypode mid astrehtum handum to pam Hoclende pus, Eala ðu min drihten, pe me to menn gesceope ${ }^{50}$; 'Well then Agatha called inwardly thus to the Saviour with her hands stretched out: Oh you my Lord, who made me a human being'. Of the holy woman Romula it is said that seo was wundorlicre gepylde man, 'she was a person of amazing patience'. ${ }^{51}$ Mary of Egypt says of herself ic eom wifhades mann, ${ }^{52}$ 'I am a female human being'. These hagiographical examples highlight the absence of similar cases in the hagiography of the Old English Martyrology, where female saints do not have their humanity underlined in this way. In that sense, authorial aims here seem to have greater semantic influence than genre conventions.

Another notable usage of mann not occurring so prominently in the Old English Martyrology is the more gender-specific meaning of mann, for example, in cases which seem to use mann in a sexual context, when wer would perhaps have been a less ambiguous choice. Ælfric uses mann in his translation of the Ten Commandments, also in the injunction not to covet one's neighbour's wife (uxor proximi, Ex 20:17, Deut 5:21): ne gewilna ðu oðres mannes wifes, 'do not desire another human being's/male's wife'; the same phrasing is also attested in penitential and legal literature. ${ }^{53}$ It is perhaps worth noting that this Commandment occurs in the context of other prohibitions concerning one's neighbour, but as the only one with a sexualised and thus gender-specific context; the accompanying prohibitions concerning the killing of another mann or the coveting of oðres mannes achta (possessions) seem more intuitively gender-neutral, and it may be that mannes wif was simply following this template. ${ }^{54}$ But Ælfric is happy to use mann in other sexualised contexts:

\footnotetext{
47 ÆCHom II, 12.1, Godden (1979, 118).

48 ChronF (Baker), Baker (2000, 33); ChronE (Irvine), Irvine (2004, 25).

49 ÆCHom II, 19, Godden (1979, 175).

50 ÆLS (Agatha), Skeat (1881-1900, I, 206).

51 GD Pref and 4 (C) Hecht (1900-1907, 283).

52 LS 23 (MaryofEgypt), Magennis (2002), 74; also cited by Fell (2002), 202.

53 ÆCHom I, 12 (Pref) Clemoes (1997, 531), ÆCHom II, 12.1 Godden (1979, 114), ÆCHom II, 12.1, Godden (1979, 119), ÆLet 3 (Wulfstan 2), Fehr (1966, 202). See also LS 35 (VitPatr), Assmann (1964, 203), and Sol I, Cross and Hill (1982, 32).

54 See Kleist (2002) for tendencies to conflate the injunctions against greed and lust, and for ÆElfric's influence on the Anglo-Saxon wording of the Ten Commandments.
} 
omnis qui uiderit mulierem ad concupiscendum (...), pæt is on Englisc, ælc man pe sceawað wifman mid luste ${ }^{55}$

omnis qui uiderit mulierem ad concupiscendum, that is in English 'each human being/male who leers after a woman'

In this case, however, celc man translates omnis, and could also be understood to function as the gender-neutral 'everybody', which as noted above, is a common collocation involving mann. The gender-neutral choice mann over wer here could thus have been influenced by the indefinite adjective aelc. Another instance of gender-specific mann used by Ælfric, cited by the $O E D$ as the earliest such usage, could have been influenced by factors other than pure semantics: in the Life of Eugenia, the female saint is disguised as a man through tonsure and male clothes. Her true nature is revealed to Bishop Helenus in a dream vision. He challenges her:

he genam hi pa onsundron and sæde hyre gewislice

hwæt heo man ne wæs and hwylcere mægpe ${ }^{56}$

He took her to one side and told her firmly

that she was no male and (asked her) what kind she was

The passage is part of a wider theme of masculinity in a text referring to Eugenia's disguise elsewhere with wer or werlic, frequently mirroring the use of vir and viriliter of the Latin source text. ${ }^{57}$ The use of mann in this context is therefore perhaps unexpected. But it needs to be pointed out that mann in this example is part of the alliteration of \#lfric's rhythmical prose, and was probably chosen to complement magpe which follows it; Ælfric is otherwise known to have adapted his vocabulary to suit aural or rhythmical effects, rather than semantic distinction, and, as Jun Terasawa has shown, this also applies to Ælfric's usage of the weak noun manna. ${ }^{58}$ Yet it seems clear in any case that at least in Ælfric's day, mann seems to have had sufficient potential as a gender-specific term in order to make Bishop Helenus' put-down meaningful. ${ }^{59}$

Other patterns found in Old English prose echo those suggested for the Old English Martyrology above: angels, where described as appearing in human shape, are designated as wer, not mann:

Pa hie pa in pone heofon locodan æfter him, \& hie Drihten gesawon upastigendne, pa stodan him twegen weras big on hwitum hræglum. ${ }^{60}$

\footnotetext{
55 Also cited by Curzan $(2003,164)$.

56 ELS (Eugenia), Skeat (1881-1900, I, 28); the passsage is referenced in Curzan (2003, 163), and is discussed in Roy (1992, 1-27, esp. 17, 23 and footnote 21).

57 For further background on Ælfric's treatment of Eugenia, see Gulley (2014, 66-81) and Clark (2009, 184-194).

58 Terasawa (2010, 31). See Godden (1980), Magennis (2009, 25-26) and Godden (1992, 514-523) for the semantic choices of Old English prose authors such as Ælfric.

59 The well-attested use of geong mann also shows ambiguity, with some examples implying genderneutral 'human being who is young', and other instances gender-specific 'male young human being', as argued by Bäck (1934, 168-171).
}

${ }^{60}$ HomS 46, Morris (1874-1880), 121. 
When they were looking into heaven after him and they saw the ascending Lord, two males were with him in white clothes.

Ælfric particularly emphasises that an angelic appearance rules out human identity:

ða ongeat he pæt se cuma wæs engel and na mann. ${ }^{61}$

Then he realised that the visitor was an angel and not a human being.

As in the Old English Martyrology, members of religious communities are frequently given gender-specific references: the collocation Godes wer is well attested; the female opposite Godes foemne occurs outside the Old English Martyrology in one other ninth-century text, the Old English translation of Gregory's Dialogi. ${ }^{62}$ Attestations of Godes mann by contrast are very frequent, especially in ninth-century texts, apparently only applied to males. A hypothetical gender-specific Godes wif seems to be unattested in this particular meaning.

Particularly common, not just in homiletic texts but also other genres, is the collocation cristene men for 'Christians', paralleled by the (sometimes indistinguishable) compound noun cristenmann. The meaning in both cases includes male as well as female Christians and is thus gender-neutral in meaning. ${ }^{63}$ The genderspecific female equivalent cristenwif is only attested in the Old English Martyrology; Cristen wer and Cristen famne do not seem to occur at all; Cristes wer also seems to be unattested, with only one example of Cristes famne. ${ }^{64}$ It appears that Godes wer and Godes fomne fill this semantic area adequately enough.

Frequent in the larger Old English prose corpus is also the combination of mann with indefinite adjectives like aenig, noenig, alc, hwilc, with translations of 'anybody', 'nobody', 'everybody', 'whosoever'. ${ }^{65}$ The association of mann with national or regional identity, encountered above in the Old English Martyrology, without being particularly common, similarly has some parallel in other prose, including examples like Romanisces cynnes mon ('a person/man of Roman origin') and hoeðenes cynnes men ('persons/men of pagan origin'). ${ }^{66}$ The combination of possessive pronouns with men (plural) is also attested outside the Old English Martyrology, with military followers implied in most cases, if not all. ${ }^{67}$ Collective references to the poor, the young, the ill, the mute, the dead in collocations involving mann are equally well-attested, with the dative plural collocations pearfendum mannum and untrumum mannum in particular. ${ }^{68}$

References to individuals setting records among mankind are also attested in other Old English prose, particularly with reference to the history of Christianity: Abraham se heahfoeder woes aerest manna ymsniden, "Abraham the patriarch was the

\footnotetext{
61 ÆCHom II, 10, Godden (1979, 83).

62 GD 1 (C) and GD 1 (H), Hecht (1900-1907, 29), and GD 2 (C), Hecht (1900-1907, 167).

63 di Paolo Healey et al. (2008), s.v. cristenmann.

64 LS 10.1 (Guth), Gonser (1909, 164).

65 Fell (2002, 205); Fröhlich (1951, 45-70), Mitchell (1985, §381).

66 Bede 1, Miller (1890-1898, 54); HomS 24 (Verc 1), Scragg (1992, 24).

67 For example, ChronE (Irvine), Irvine (2004, 124); HomS 24 (Verc 1), Scragg (1992, 32).

68 For example, HomS 40.3 (Verc 10), Scragg (1992, 203); ÆCHom I.12, Clemoes (1997, 275).
} 
first human being/male to be circumcised' ${ }^{69}$ But the distinction between individual and generic usage is perhaps best exemplified in the famous statement about Caedmon, implying that his talent had been divinely and not humanly inspired, he nales from monnum ne purh mon gelcered woes, 'he had not at all been taught by human beings, nor through [the agency of] man' ${ }^{70}$ Relatively common in Old English prose are also references to the human body, human conduct, or human soul or salvation involving gender-neutral mann, often in collocations involving mannes or manna and particularly in homiletic literature and medical texts. ${ }^{71}$

Finally, several Anglo-Saxon glossaries relate mann to Latin homo and Greek $\alpha \approx \nu \theta \rho \omega \pi$ ○ ; by contrast, there seem to be no attestations of similar glosses equating mann with Latin vir. ${ }^{72}$

\section{Conclusion}

Dictionaries of Old English are among the most important current resources for the usage of OE mann, while a systematic exploration of all attestations and a detailed lexical entry remain desiderata. Existing resources indicate that OE mann is semantically asymmetrical (in the sense that it is attested in gender-neutral and gender-specific male usage). The pilot study presented here, backed up with relevant examples from other prose texts, shows widespread usage of the ungendered meaning (especially in plural forms), with only isolated examples of the word being applied to named (and thus gendered) individuals. Although mann can theoretically refer to a named (especially saintly) woman, it rarely does. Explicit gender-specific usage of mann for males (e.g., in sexualised contexts) seems to be similarly rare; this gender-specific meaning seems to be restricted to certain authors and very specific contexts. The sample literature discussed here is unfortunately not representative enough for an assessment of diachronic developments within the Anglo-Saxon period. Further, more extensive studies, perhaps with particular focus on Ælfric, Anglo-Saxon laws and medical texts, are clearly required.

An important implication for translators is the need to overcome what Fell regarded as 'centuries of mistranslation' of mann, in taking care not to make Old English texts sound 'much more male-oriented' than intended by their authors (Fell 2002, 203 and 215). This is perhaps best done by adherence to lexis which is ambiguous in its gender-specificity also in modern English. Anne Curzan points out that 'it seems possible for gender-neutral and gender-specific meanings of one word to coexist for some period of time when the gender-specific reference is coming into use, but once the gender-specific meaning becomes dominant, the gender-neutral

\footnotetext{
69 ÆCHom I.6, Clemoes (1997, 224). On this usage, see also Fell (2002, 202).

70 Bede 4, Miller (1890-1898, 342); the Latin source has 'ipse non ab hominibus neque per hominem institutus canendi artem didicit', Colgrave and Mynors (1969, 414), which itself cites Galatians 1:1, 'non ab hominibus neque per hominem'.

71 See, for example, ÆCHom II.1, Godden (1979, 8), Donne beoð geopenode blindra manna eagan and deaffra manna earan gehyrað, or the note on the formation of the human foetus, Chardonnens (2007, 229).

72 See, for example, BrGl 1, Wright and Wülcker (1884, col. 289), 'Homo, man; Antropus, man'.
} 
one must become peripheral' (Curzan 2003, 157). As modern English usage moves further away from the increasingly peripheral gender-neutral usage of man ('human being'), it will be important for modern scholarship to acquire a nuanced understanding of the complexities of the Old English usage of mann.

Acknowledgments Many thanks to Rolf Bremmer, Mary Clayton and Lucia Kornexl for bibliographical information; I am also grateful for the helpful comments made by audiences in Hull, Leiden and Manchester.

Open Access This article is distributed under the terms of the Creative Commons Attribution 4.0 International License (http://creativecommons.org/licenses/by/4.0/), which permits unrestricted use, distribution, and reproduction in any medium, provided you give appropriate credit to the original author(s) and the source, provide a link to the Creative Commons license, and indicate if changes were made.

\section{References}

Arbellot, F. (Ed.) (1892). Vita S. Martialis (BHL 5551) and Miracula S. Martialis (BHL 5561), Étude historique sur l'ancienne Vie de Saint Martial. Bulletin de la société archéologique et historique du Limousin 40: 213-260, at 238-248.

Assmann, B. (Ed.). (1964). Angelsächsische Homilien und Heiligenleben. Bibliothek der angelsächsischen Prosa 3, reprinted with introduction by P. Clemoes. Darmstadt: Wissenschaftliche Buchgesellschaft.

Bäck, H. (1934). The synonyms for 'child', 'boy', 'girl' in Old English: An etymological-semasological investigation. Lund Studies in English 2. Lund: C. W. K.Gleerup.

Baker, P. S. (Ed.). (2000). The Anglo-Saxon Chronicle: A collaborative edition. Vol. 8: MS. F. Cambridge: D. S. Brewer.

Bammesberger, A. (1999). Mannum/Manno bei Tacitus und der Name der m-Rune. Beiträge zur Namenforschung, 34, 1-8.

Bammesberger, A. (2000). Urgermanisch *mann-: Etymologie und Wortbildung. Studia Etymologica Cracoviensia, 5, 7-12.

Bankert, D. (Forthcoming). God and man in Old English: The lexical construction of the cultural past.

Baron, D. (1986). Grammar and gender. New Haven: Yale University Press.

Bennett, N. R. (2012). The Christology of the Anglo-Saxon homilies. Unpubl. Ph.D. Dissertation, University of Cambridge.

Blake, M. (Ed.). (2009). Alfric's De temporibus anni. Anglo-Saxon Texts 6. Cambridge: D. S. Brewer. Bosworth, J., \& Toller, T. N. (1882-1898). An Anglo-Saxon dictionary. Oxford: Clarendon Press. With a Supplement by T. N. Toller (1921) and an Addendum by A. Campbell (1972).

Bultmann, R. (1963). The history of the synoptic tradition (trans: Marsh, J.). Blackwell, Oxford.

Cameron, A., Kingsmill, A., \& Amos, A. C. (1983). Old English word studies: A preliminary author and word index. Toronto: University of Toronto Press.

Campbell, A. (1959). Old English grammar. Oxford: Clarendon Press.

Chardonnens, L. S. (Ed.). (2007). Anglo-Saxon prognostics 900-1100: Study and texts. Brill's Studies in Intellectual History 153. Leiden: Brill.

Chase, D. E. (1977). A semantic study of Old English words for warrior. Unpubl. Ph.D. Dissertation, University of New York.

Clark, D. (2009). Between medieval men: Male friendship and desire in early medieval English literature. Oxford: Oxford University Press.

Clark Hall, J. R. (1960). A concise Anglo-Saxon dictionary (4th ed.). With a Supplement by H. D. Meritt. Cambridge: Cambridge University Press.

Clemoes, P. A. M. (Ed.). (1997). AElfric's Catholic Homilies: The first series, text. Early English Text Society s. s. 17. Oxford: Oxford University Press.

Coleman, J. (1999). Love, sex and marriage: A historical thesaurus. Amsterdam: Rodopi.

Colgrave, B., \& Mynors, R. A. B. (Eds.). (1969). Bede's ecclesiastical history of the English people. Oxford: Clarendon Press. 
Cross, F. L., \& Livingstone, E. A. (1997). Oxford Dictionary of the Christian Church (ODCC) (3rd ed.). Oxford: Oxford University Press.

Cross, J. E., \& Hill, T. D. (Eds.). (1982). The Prose Solomon and Saturn and Adrian and Ritheus. Toronto: University of Toronto Press.

Curzan, A. (2003). Gender shifts in the history of English. Cambridge: Cambridge University Press.

De Vaan, M. (2008). Etymological dictionary of Latin and the other Italic languages. Leiden IndoEuropean Etymological Dictionary Series 7. Leiden: Brill.

di Paolo Healey, A., et al. (Eds.). (2005). Dictionary of Old English Corpus (DOEC). Toronto. http:// quodlib.umich.edu/o/oec. Accessed 11 February 2016.

di Paolo Healey, A., et al. (Eds.). (2008). Dictionary of Old English: A-G on CD-ROM (DOE). Toronto: Pontifical Institute of Mediaeval Studies.

Dobbie, E. V. K. (Ed.). (1942). The Anglo-Saxon minor poems. ASPR 6. London: Routledge.

Fehr, B. (Ed.). (1966). Die Hirtenbriefe Alfrics. Bibliothek der angelsächsischen Prosa 9, reprinted with supplement by P. Clemoes. Darmstadt: Wissenschaftliche Buchgesellschaft.

Fell, C. (1984). Women in Anglo-Saxon England. London: British Museum Publications.

Fell, C. (2002). Words and women in Anglo-Saxon England. In C. Hough \& K. A. Lowe (Eds.), Lastworda betst: Essays in memory of Christine E. Fell (pp. 198-215). Donington: Shaun Tyas.

Frantzen, A. J. (1996). Between the lines: Queer theory, the history of homosexuality, and Anglo-Saxon penitentials. Journal of Medieval and Early Modern Studies, 26, 255-296.

Frantzen, A. J. (2012). Anglo-Saxon keywords. Chichester: Wiley-Blackwell.

Fröhlich, J. (1951). Der indefinite Agens im Altenglischen unter besonderer Berücksichtigung des Wortes man. Schweizer Anglistische Arbeiten 2. Bern: Francke.

Fulk, R. D. (2004). Male homoeroticism in the Old English canons of Theodore. In C. Pasternack \& L. M. C. Weston (Eds.), Sex and sexuality in Anglo-Saxon England: Essays in memory of Daniel Gillmore Calder (pp. 1-34) Medieval and Renaissance Texts and Studies 277. Tempe: Arizona Center for Medieval and Renaissance Studies.

Godden, M. (Ed.). (1979). AElfric's Catholic Homilies: The second series, text. Early English Text Society s. s. 5. London: Oxford University Press.

Godden, M. (1980). Ælfric's changing vocabulary. English Studies, 61, 206-223.

Godden, M. (1992). Literary language. In R. Hogg (Ed.), The Cambridge history of the English language Vol. I: The beginnings to 1066 (pp. 490-535). Cambridge: Cambridge University Press.

Godden, M. (2000). Alfric's Catholic Homilies: Introduction, commentary and glossary. Early English Text Society s. s. 18. Oxford: Oxford University Press.

Gonser, P. (Ed.). (1909). Das angelsächsische Prosa-Leben des heiligen Guthlac. Anglistische Forschungen 27. Heidelberg: C. Winter.

Grygiel, M. (2004). Semantic changes within the domain BOY in panchronic perspective. Studia Anglica Posnaniensia, 40, 153-162.

Grygiel, M. (2006). On the cyclicity of meaning alternations in English historical synonyms of MAN/ MALE HUMAN BEING. In R. McConchie, et al. (Eds.), Selected proceedings of the 2005 symposium on new approaches in English historical lexis (HEL-LEX) (pp. 60-68). Somerville, MA: Cascadilla Press.

Grygiel, M. (2008). From semantic change to conceptual blending: semantic development of English historical near-synonyms of MAN/MALE HUMAN BEING. Rzeszów: Wydawnictwo UR.

Gulley, A. (2014). The displacement of the body in Alfric's virgin martyr lives. Farnham: Ashgate.

Hastings, A., Mason, A., \& Pyper, H. (Eds.). (2000). The Oxford companion to Christian thought. Oxford: Oxford University Press.

Hecht, H. (Ed.) (1900-1907). Bischof Warferths von Worcester Übersetzung der Dialoge Gregors des Grossen. Bibliothek der angelsächsischen Prosa 5. Leipzig: G. H. Wigand.

Hellinger, M. (1990). Kontrastive feministische Linguistik: Mechanismen sprachlicher Diskriminierung im Englischen und Deutschen. Ismaning: M. Hueber.

Herzfeld, G. (Ed.). (1900). An Old English Martyrology. Early English Text Society o. s. 116. London: Kegan Paul, Trench, Trübner et al.

Hogg, R. M. \& R. D. Fulk (1992-2011). A grammar of Old English, 2 vols. Chichester: Blackwell.

Holthausen, F. (1963). Altenglisches etymologisches Wörterbuch (2nd ed.). Heidelberg: C. Winter.

Hughes, G. (2000). A history of English words. Oxford: Blackwell.

Irvine, S. (Ed.). (2004). The Anglo-Saxon Chronicle: A collaborative edition. Vol. 7: MS. E. Cambridge: D. S. Brewer. 
Jespersen, O. (1949). A modern English grammar on historical principles (Vol. 7). Copenhagen: Ejnar Munksgaard.

Kastovsky, D. (1992). Semantics and vocabulary. In R. M. Hogg (Ed.), The Cambridge history of the English language: Volume I, The beginnings to 1066 (290-408) (pp. 290-408). Cambridge: Cambridge University Press.

Kastovsky, D. (1999). Inflectional classes, morphological restructuring, and the dissolution of Old English grammatical gender. In B. Unterbeck, et al. (Eds.), Gender in grammar and cognition. (pp. 709-27). Trends in linguistics studies and monographs 124. Berlin: M de Gruyter.

Kjellmer, G. (1973). Middle English words for 'people'. Acta Universitatis Gothoburgensis: Gothenburg Studies in English 27. Stockholm: Almkvist \& Wiksell.

Kleist, A. J. (2002). The division of the ten commandments in Anglo-Saxon England. Neuphilologische Mitteilungen, 103, 227-240.

Kleparski, G. A. (1996). Diachronic analysis of the concept 'boy'. In G. Persson \& M. Rydén (Eds.), Male and female terms in English: Proceedings of the symposium at Umeå University, May 18-19, 1994 (pp. 69-78). Umeå: Umeå University.

Kleparski, G. A. (2003). Churls, harlots and sires: The semantics of Middle English synonyms of man. Studia Anglica Posnaniensia, 39, 47-55.

Kluge, F., \& Seebold, E. (2011). Etymologisches Wörterbuch der deutschen Sprache. (25th ed.). Ed. E. Seebold. Berlin: de Gruyter.

Kornexl, L. (2006). Female husbands in Old English lexicography. In A. J. Johnston, F. von Mengden, \& S. Thim (Eds.), Language and text: Current perspectives on English and Germanic historical linguistics and philology (pp. 169-178). Heidelberg: Winter.

Kroonen, G. (2013). Etymological dictionary of Proto-Germanic. Leiden Indo-European Etymological Dictionary Series 11. Leiden: Brill.

Kornexl, L. (2009). Geschlechterdifferenz und ihre sprachliche Markierung: Zur historischen Entwicklung der personalen Wortbildung im Englischen. In H. Ehlers, H. Kahlert, G. Linke, D. Raffel, B. Rudlof, \& H. Trappe (Eds.), Geschlechterdifferenz-und kein Ende? Sozial- und geisteswissenschaftliche Beiträge zur Genderforschung (pp. 79-96). Berlin: Lit Verlag.

Lass, R. (1994). Old English: A historical linguistic companion. Cambridge: Cambridge University Press.

Latham, R. E., \& Howlett, D. R. (Eds.). (1989). Dictionary of medieval Latin from British sources (DMLBS) Fascicule 4. Oxford: Oxford University Press.

Lewis, C. T., \& Short, C. (1879). A Latin dictionary. Oxford: Clarendon Press.

Liebermann, F. (Ed.). (1903-1916). Die Gesetze der Angelsachsen. Niemeyer, Halle.

Loomis, C. G. (1991). Three cases of vaginism. In J. E. Salisbury (Ed.), Sex in the middle ages: A book of essays (pp. 237-238). Garland Medieval Casebooks 3. New York: Garland Publications.

Louw, J. P., \& Nida, E. A. (1989). Greek-English lexicon of the New Testament based on semantic domains (2nd ed.). New York: United Bible Societies.

Magennis, H. (Ed.). (2002). The Old English life of Saint Mary of Egypt: An edition of the Old English text with Modern English parallel-text translation. Exeter: University of Exeter Press.

Magennis, H. (2009). Ælfric scholarship. In H. Magennis \& M. Swan (Eds.), A companion to Alfric (pp. 5-34). Brill's Companion to the Christian Tradition 18. Brill: Leiden.

Meyer-Lübke, W. (1935). Romanisches etymologisches Wörterbuch (3rd ed.). Heidelberg: C. Winter.

Middle English Dictionary (MED). http://quod.lib.umich.edu/m/med

Miller, T. (Ed.) (1890-1898). The Old English version of Bede's Ecclesiastical History of the English People, 4 vols. Early English Text Society o. s. 95, 96, 110, 111. London: Trübner.

Mitchell, B. (1982). Old English man 'one': Two notes. In J. Anderson (Ed.), Language form and linguistic variation: Papers dedicated to Angus McIntosh (pp. 277-284). Amsterdam Studies in the Theory and History of Linguistic Science 4.15. Amsterdam: J. Benjamins.

Mitchell, B. (1985). Old English syntax, 2 vols. Oxford: Clarendon Press.

Morris, R. (Ed.) (1874-80). The Blickling Homilies, 3 vols. Early English Text Society o. s. 58, 63, 73. London: Oxford University Press.

Napier, A. S. (Ed.). (1883). Wulfstan: Sammlung der ihm zugeschriebenen Homilien nebst Untersuchungen über ihre Echtheit. Sammlung englischer Denkmäler 4. Berlin: Weidmann.

O'Brien, J. (Ed.). (2014). The Oxford encyclopedia of the Bible and gender studies. Oxford: Oxford University Press.

Oxford English Dictionary (OED). www.oed.com. Accessed 11 February 2016. 
Persson, G., \& Rydén, M. (1995). The project 'Male and female terms in English': A diachronic study of a semantic field. In H. Kardela \& G. Persson (Eds.), New trends in semantics and lexicography (pp. 145-150). Acta Universitatis Umensis 127. Umeå: Umeå.

Persson, G., \& Rydén, M. (1996). Male and female terms in English: Proceedings of the symposium at Umeå University, May 18-19, 1994. Umeå: Umeå University.

Pokorny, J. (1948-1969). Indogermanisches etymologisches Wörterbuch, 2 vols. Francke, Bern.

Ramat, P. (1963). Il gotico manna e i suoi composti. Die Sprache, 9, 23-34.

Rauer, C. (2013a). Female hagiography in the Old English Martyrology. In P. E. Szarmach (Ed.), Writing women saints in Anglo-Saxon England (pp. 13-29). Toronto: University of Toronto Press.

Rauer, C. (Ed.). (2013b). The Old English Martyrology: Edition, translation and commentary. AngloSaxon Texts 10. Cambridge: D. S. Brewer.

Riedinger, A. R. (1994). Lexical inequities in marriage: Old English wif, wer, and husbonda. Studia Neophilologica, 66, 3-14.

Roberts, J., Kay, C., \& Grundy, L. (1995). A Thesaurus of Old English, 2 vols. King's College London Medieval Studies 11. London: Centre for Late Antique and Medieval Studies, King's College.

Rolleston, J. D. (1991). Penis captivus: A historical note. In J. E. Salisbury (Ed.), Sex in the Middle Ages: A book of essays. (pp. 232-237). Garland Medieval Casebooks 3. New York: Garland Publications.

Roy, G. (1992). A virgin acts manfully: Ælfric's Life of St Eugenia and the Latin versions. Leeds Studies in English ns, 23, 1-27.

Scheller, A. (2010). Bezeichnungen für die christliche Gottheit im Altenglischen. Hamburg: Verlag Dr. Kovač.

Scragg, D. G. (Ed.). (1992). The Vercelli Homilies and related texts. Early English Text Society o. s. 300. Oxford: Oxford University Press.

Skeat, W. W. (Ed.) (1881-1900). Alfric's Lives of Saints, 4 vols. Early English Text Society o. s. 76, 82, 94, 114. London: Trübner.

Stenroos, M. B. (2002). Words for MAN in the transmission of Piers Plowman. In Díaz Vera, J. E. (Ed.), A changing world of words: Studies in English historical lexicography, lexicology and semantics (375-409). Costerus new series 141. Amsterdam: Rodopi.

Stibbe, H. (1935). 'Herr' und 'Frau' und verwandte Begriffe in ihren altenglischen Äquivalenten, Anglistische Forschungen 80. Heidelberg: C. Winter.

Stodnick, J. (2013). Bodies of land: The place of gender in the Old English Martyrology. In P. E. Szarmach (Ed.), Writing women saints in Anglo-Saxon England (pp. 30-52). Toronto: University of Toronto Press.

Stotz, P. (1998). Handbuch zur lateinischen Sprache des Mittelalters (Vol. 4). Munich: C. H. Beck.

Terasawa, J. (2010). The weak man in Old English poetry. Journal of English and Germanic Philology, $109,22-32$.

Theissen, G. (1983). The miracle stories of the early Christian tradition (trans: McDonagh, F. \& Riches, J.). Edinburgh: T. \& T. Clark.

van Bergen, L. (2003). Pronouns and word order in Old English with particular reference to the indefinite pronoun man. New York: Routledge.

van der Loos, H. (1965). The miracles of Jesus. Leiden: Brill.

von Lindheim, B. (1958). Die weiblichen Genussuffixe des Altenglischen. Anglia, 76, 479-504.

Whatley, E. G. (2001). Acta Sanctorum. In F. M. Biggs, et al. (Eds.), Sources of Anglo-Saxon literary culture: Volume one (pp. 22-548). Kalamazoo: Medieval Institute Publications, Western Michigan University.

Wright, T., \& Wülcker, R. P. (Eds.). (1884). Anglo-Saxon and Old English vocabularies, 2 vols (2nd ed.). Ed. R. P. Wülcker. London: Trübner. 